\author{
ILDIKÓ LAKI \\ Milton Friedman University - Budapest (Hungary) \\ b.laki.ildiko@gmail.com
}

ORCID ID: 0000-0003-1907-7633

\title{
RIGHT TO EDUCATION - YOUNG PEOPLE WITH DISABILITIES AND CHILDREN WITH SPECIAL EDUCATIONAL NEEDS
}

\begin{abstract}
"The analysis of the discourses about people with disabilities has become of central importance in the Western societies because it is becoming increasingly clear that these ways of speaking play a fundamental role in the formation and maintenance of the socio-political positions of people with disabilities. In fact, there can be no doubt that the discourses about people with disabilities do not simply have political and social consequences, but are linked to clearly direct, although often hidden political processes. "'
\end{abstract}

\section{THOUGHT-PROVOKING - INTRODUCTION}

One of the biggest educational challenges of the past decades is the question of the social and educational integration of young people with special educational needs (SEN) and/or youth and young adults with disabilities. The importance of the topic is provided by two factors; there is a clearly rising trend in the increase in the number of children with special educational needs, which can be identified almost immediately among the children due to the methodological results, on the one hand, and it has become a feature of the public education that was able to launch many segments of the market - developments, movement therapy, complex forms of education based on special needs - and, as a result, industries are slowly beginning to emerge to create opportunities for them to enter the system, on the other hand.

In the case of the public education, the SEN category also represents a kind of set of problems, because in the case of students who study at a normal pace, those belonging to the SEN group only experience disadvantages.

1 V. Kiss (2013): The policy of wholeness: Discourses about disability and the ideologies of normality in Hungary. In: I. Laki, (ed.) (2013) A 21st century overview of the international and domestic disability policies. L'Harmattan, Budapest. 
The purpose of this summary is, on the one hand, to describe the concept and the framework of the content of the special educational needs used in the public education, and, on the other hand, to summarize the types of disabilities in the light of such data. The study also seeks to give an answer to the question how the determination of the disability is able to reflect a specific educational need, and shed light on the usable, more relevant concept from the perspective of the interested persons.

\section{CONCEPTUAL MATTERS}

"The education of children and young people with special educational needs (SEN) is a special area of care in the system of public education. Although the education of SEN children, ensuring that the knowledge and the competences detailed in the basic curriculum of the given system of public education are gained, is subject to special professional conditions, the existence and the level of operation of such conditions show the quality of the whole system of education, while its unresolved issues affect the whole system of the public education."

In Hungary, the use of the term "disability", in the field of public education, has been replaced by the term "child or student with special educational needs" in recent years. This concept was first introduced in Act LXXIX of 1993 on Public Education, as amended several times. In Act CXC of 2011 on National Public Education, a child with a disability means a child with special educational needs.

The law distinguishes between children and students who need special attention. In this sense: children or students who need special treatment belong to the following groups:

- children, students with special educational needs,

- children, students with integration, learning and behavioural difficulties,

- highly talented children, students,

as well as the disadvantaged and cumulatively disadvantaged children or students under the Act on child protection and guardianship administration.

According to the Act, the children and students with special educational needs (SEN) also belong here: "the children or students with special educational needs (SEN) are children or students who need special treatment, who, according to the expert opinion of the expert committee, have musculoskeletal, sensory, intellectual or speech disabilities, are cumulatively disabled in the

2 V. Csépe (2007): The practice of caring for children in need of special education, teaching and development for rehabilitation purposes (SEN), and the necessary actions. Source: http://econ.core.hu/file/download/zk/zoldkonyv_oktatas_06.pdf . 
case of multiple disabilities, and struggle with autism spectrum disorders or other psychiatric developmental disorders (severe learning, attention, or behavioural disorder). ${ }^{3}$

The concept of special educational need is used in the methodology of public education, while, in the everyday life, the concept of people with disabilities is used in scientific studies and evaluations, in the writing and evaluation of professional documents.

"Disability" is a summary term for a large number of different functional limitations that are found in any group of people (population) in any country of the world. The disability may be caused by physical, mental or sensory impairment, health condition or mental illness. These issues, conditions or diseases may be of a permanent or of temporary nature." (MEOSZ - National Society of Associations for People with Disabilities, 1995)

"Disability is an unfavourable change in a person's abilities affecting the satisfaction of the personal, social, occupational or legal requirements and obligations expected from the person, due to the damage. The disability always refers to a specific activity (self-sufficiency disability, mobility disability, visual disability, hearing disability, etc.). The disability may be partial or complete, and may be classified as mild, slight, moderate or severe."

Examining the conceptual framework of special educational needs (SEN) and/or disability, we can conclude that not all students with SEN are persons with disabilities, and not all people with disabilities are students with SEN. At the same time, this definition is an integral part of the everyday public education, which is properly showed by the current state of the educational data.

3 Summary based on: Act CXC of 2011 on National Public Education, Section 4\$, Paragraph 25. Source: https://net.jogtar.hu/jogszabaly?docid=a1100190.tv.

4 B. Kapitány, (2015): Glossary of Demographic Terms. CSO Population Research Institute, Budapest, p. 29 http://demografia.hu/hu/letoltes/kiadvanyok/Demografiai-Fogalomtar.pdf. 
Figure no. 1

Preliminary statistics for public education and school-based vocational education in the school year 2020/2021 - for students/children with special educational needs

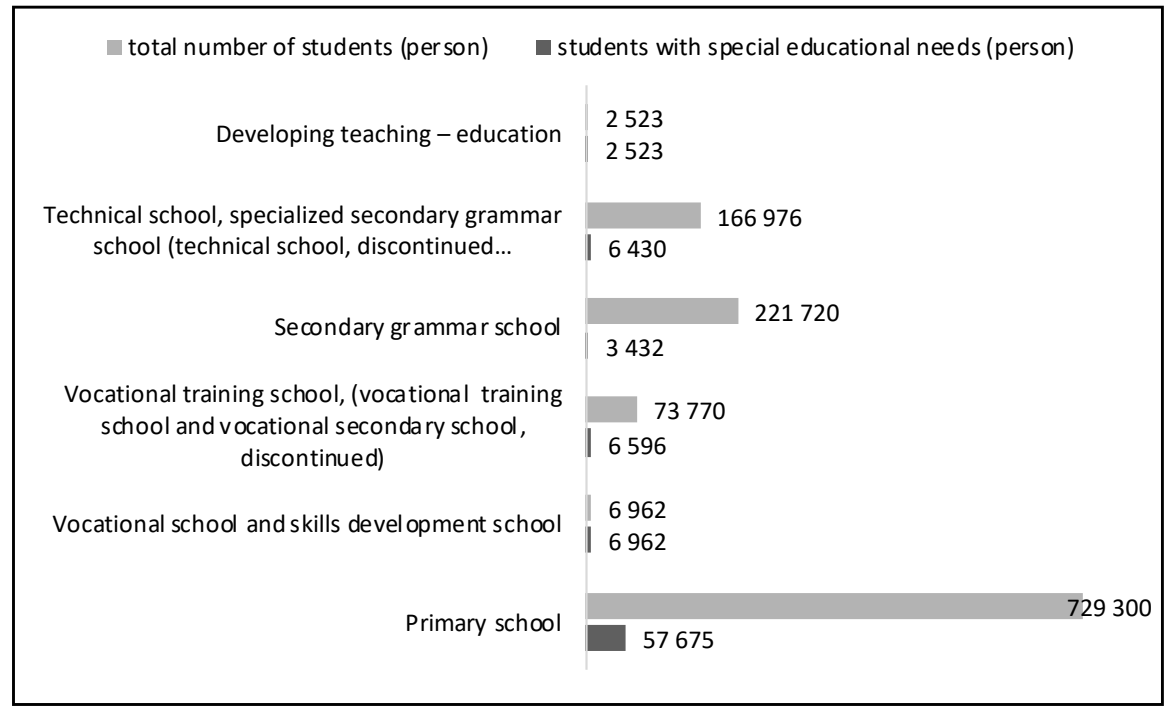

Source: http://www.ksh.hu/docs/hun/xftp/idoszaki/oktat/oktatas2021e/index.html KSH (CSO - Central Statistics Office, 2020.

The above data show that most children with special educational needs are in the primary school, the second stage of public education, which number eventually decreases to one tenth when they enter the secondary school.

Here we need to make two assumptions. Primarily, the main question is whether the special educational need is eliminated for the next stage of the education and it is removed thus from the child, or they only finish the primary school classes and are no longer included in the later statistics. The question remains to be answered, because further researches are necessary to make it clear. 


\section{INCLUSION AND INTEGRATION IN THE PATH OF THE PUBLIC EDUCATION}

The concept of inclusion, approached from the ideas of Niklas Luhmann, is the presence in the system. "In his theory, the inclusion refers to a state when a person is inside a system or subsystem." ${ }^{5}$

The concept of integration has no properly defined content in the sociology. It means strong interdependence, close connection and belonging to each other in the science, and in the everyday life.

"Integration means to ensure the participation of people with disabilities in the social processes; and as a pedagogical task, it attempts to help the learning of disabled and healthy children using didactic and methodological tools."

The basic principle of inclusive schools is that all children should learn together, as far as possible, regardless of the difficulties and the differences that may arise. The inclusive schools need to recognize the different needs of the students and adapt to them, both in terms of the learning and the teaching styles and the content of the education, providing high-quality education for everyone, with a proper curriculum, organization, teaching strategy, use of resources and through ongoing contact with the given communities.

The question remains, however, whether all the participants of the public education are able to ensure inclusiveness while facing such difficulties, individual characteristics and peculiarities. If we summarize the research as well as our own experience, it can be clearly stated that the answer is "no". This is supported by a study by Erdei, in which he attempts to interpret inclusivity and integration through different points of approach.

Bánfalvy, Cs. (editor) (2008) Integration tsunami. Studies on the school and social integration of people with disabilities. ELTE Gusztáv Bárczi College of Special Education, Budapest.

6 N. Erdei, (2016): The history of the rejection and acceptance of people with disabilities to this day and their position in today's education system. Special Treatment, Volume II 2016/3, p. 44 Source: http://real.mtak.hu/80365/1/KB2016-3-041-E-1001-65XXXXXX0-Erdei.pdf . 
In his opinion, "integration, which in today's sense is also called rigid integration Mrs. Varga, consists of the following points: ${ }^{7}$

- the host institution does not have an integration strategy

- the teacher does not change their methods, or changes them slightly

- solving the problems is entirely the task of the special education teacher and the parent

- the special education teacher teaches the child in a separate room. "8

Inclusive teaching, on the other hand, represents the highest level of co-education; the inclusion and the acceptance, and implements the adaptive education, as well. It provides carefully considered and differentiated education tailored to the individual abilities and needs. "The teachers of the majority schools accept this solution; they do not draw a strong line between pupils/ students with disabilities/special educational needs and other children, because anyone may have difficulties in learning. It builds on partnership, and the special education teacher primarily provides assistance to the teacher, and the assistance is provided to the child within the classroom". (Erdei quotes Réthy)

The successful path of life of students with special educational needs is positively facilitated by their learning together with students without special educational needs. The pupils without special educational needs can thus become more sensitive and inclusive, so the social need that focuses on the principles of equal treatment may also be met. This has a key role in the case of public education, and social acceptance must be made a feature of the age group, which facilitates the laying of the pillars of a society based on justice in the future.

\section{SPECIFIC QUESTIONS, SPECIAL ANSWERS}

"The proportion of students with special educational needs in the primary and secondary education increased from 3.6 to 6.9\% between 2001 and 2018. Analysing the primary and the secondary education separately, we see that while

\footnotetext{
J. Varga (2019): The public education's indicator system. Research Centre for Economics and Regional Sciences, Institute of Economics, Budapest Source: https://www.mtakti.hu/ wp-content/ uploads/2020/01/A_kozoktatas_indikatorrendszere_2019.pdf.

8 Erdei, op. cit., p. 44.
} 
the proportion of students with SEN has changed only slightly among the 1 to 8-year students between 2005 and 2018, it has increased from 2.3 per cent to 6.0 per cent in the secondary education over the same period."9

Figure no. 2

The proportion of students with special educational needs (SEN), national data (\%)

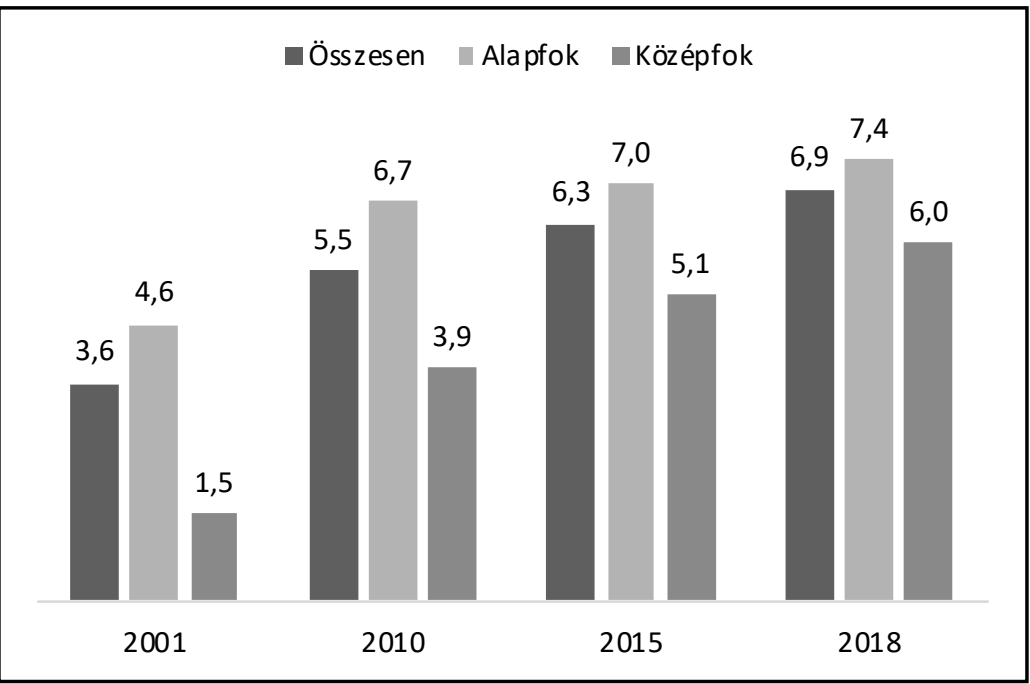

Source: The public education's indicator system, 2019

"In the 2020/2021 school year, 1 million 812 thousand children and young people participate in the various levels of education in the public education, vocational training and higher education. 729.3 thousand students receive primary education and 469.5 thousand students receive secondary education in Hungary. 2.5 thousand children with severe and multiple disabilities fulfil their compulsory education within the framework of skills development training and education." (Office of Education, 2020-2021, 2020)

Without the nursery schools, 1,201,251 persons visit educational institutions, of which $7.8 \%$ (93,736 persons) are students with special educational needs.

As for the years, the proportion of SEN students is almost gradually increasing in years 1 to 7 , and some decrease is only observed from year 9 .

9 J. Varga (2019): The public education's indicator system. Research Centre for Economics and Regional Sciences, Institute of Economics, Budapest, p. 30, Source: https://www.mtakti.hu/ wp-content/ uploads/2020/01/A_kozoktatas_indikatorrendszere_2019.pdf. 
So the numbers are gradually decreasing in the secondary schools, whether it is a secondary grammar school or any other type of secondary school institution. Further dilemmas emerge in this case, because, at this point, the large number of SEN students, leaving this framework, may continue their studies.

Figure no. 3

The proportion of students with special educational needs (SEN), breakdown by years (\%)

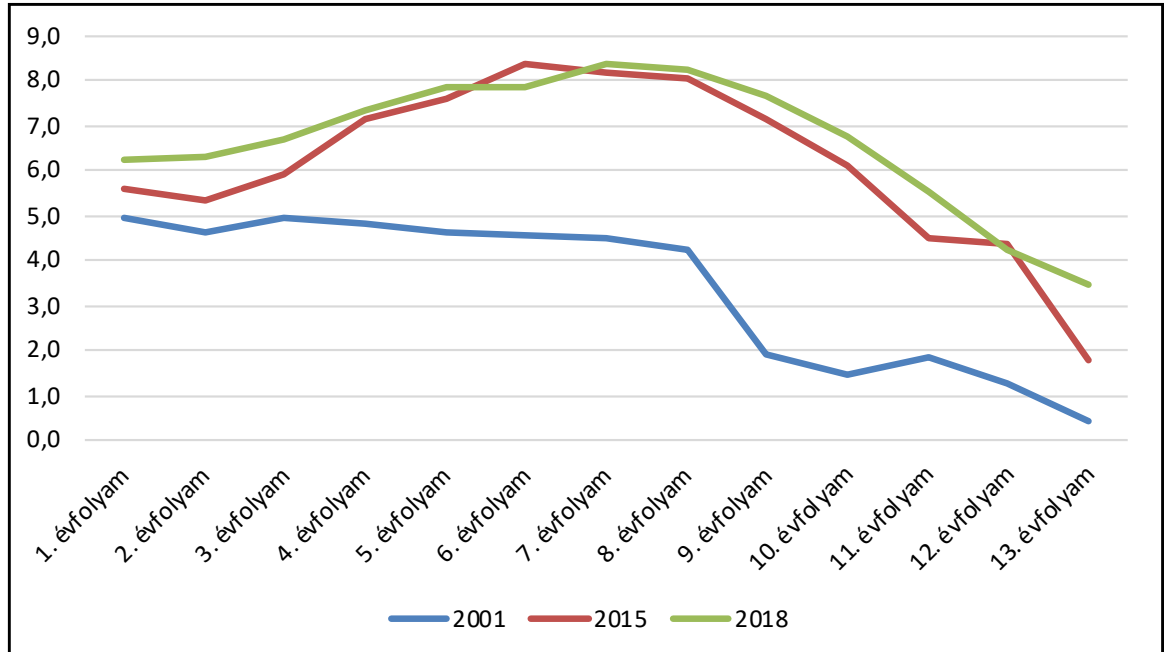

Source: The public education's indicator system, 2019

The special educational need and the special life situation of living with a disability determine the future of the individual/pupil /student and his or her participation in all areas of the social life. In this respect, it is therefore a responsibility to determine whether a child actually requires special education. Society does not take kindly to differences that greatly influence the smooth role of education and the labour market, the question of the integration of an individual. A further disadvantage is the totality of the factors that mean the attitude of the participants in these areas. The responsibility and helpful intention of the teachers and educators participating in the education have a profound effect on the lives of the pupils and students participating in the education. In addition to the basic educational activities, educational and integration tasks complement the everyday tasks, which are of primary importance for the pupils in this group. 


\section{SUMMARY}

We have reviewed the SEN students and their general situation, as well as their 'positions' in the public education in this short study. The question today is, and has been for a long time, the potential and modern way of teaching students with special needs, or rather the issue of solving their professional care. At the same time, it is not a negligible mission that, in terms of the education market, and in addition to the general service function of public education, the tools, the institutions and the opportunities appropriate for the examined population should be brought to their attention.

The number of students with SEN keeps increasing year by year, however, in many cases, the institutional structure is not able to handle the appearance of the affected group. In fact, some stages of the public education are not prepared for their "reception," which causes a number of dissonances, influencing the further life path of the individual, and the efforts to solve the social challenges.

An important stage in the study has been to review the scope of the concept of inclusion and integration and their broad interpretation, incorporating the alternative ways of the implementation of inclusive education. Based on the above, the statement that the often voiced ideas of inclusive education in public education, the principle of equal treatment and the idea of unconditional acceptance, contradict the social manifestations people feel in reality can only be made cautiously.

The unresolved problem of the students with special educational needs can be felt stronger and stronger throughout the system of public education. Although many positive efforts are facilitating the achievement of integration and/or inclusion, it seems that the growing number of students with SEN is still moving uncertainly in the system of public education. 


\section{REFERENCES}

Bánfalvy, Cs. (editor). (2008). Integration tsunami. Studies on the school and social integration of people with disabilities. ELTE Gusztáv Bárczi College of Special Education. Budapest.

Raymond, B. et al. (1998). Sociological Lexicon. Corvina. Budapest.

Boundon, R., Besnard, P., Cherkaoui, M., Lécuyer, B-P. (1998). Lexicon of Sociology. Corvina. Budapest. Data on education, 2020/2021 (preliminary data) CSO. 2020. Source: http://www.ksh.hu/docs/ hun/xftp/idoszaki/oktat/oktatas2021e/index.html

Csépe, V. (2007). The practice of caring for children in need of special education, teaching and development for rehabilitation purposes (SEN), and the necessary actions. Source: http://econ.core.hu/file/download/zk/zoldkonyv_oktatas_06.pdf

Erdei, N. (2016). The history of the rejection and acceptance of people with disabilities to this day and their position in today's education system. Special Treatment, Volume II 2016/3. Source: http://real.mtak.hu/80365/1/KB2016-3-041-E-1001-65XXXXXX0Erdei.pdf

Kapitány, B. (2015). Glossary of Demographic Terms. CSO Population Research Institute, Budapest. http://demografia.hu/hu/letoltes/kiadvanyok/Demografiai-Fogalomtar. pdf

Kiss, V. (2013). The policy of wholeness: Discourses about disability and the ideologies of normality in Hungary. In: I. Laki, (ed.) (2013) A 21st century overview of the international and domestic disability policies. L'Harmattan. The basic rules of equal opportunities for people with disabilities. MEOSZ, Budapest Source: https:// tamogatosegitseg.hu/pdf/a_fogyatekossaggal_elo_emberek_eselyegyenlosegenek_ alapveto_szabalyai.pdf

Laki, I., Tóth, L. (2013). Definition of the frameworks of life by the laws. In: I. Laki, (ed.) (2013) A 21st century overview of the international and domestic disability policies. L'Harmattan, Budapest

Varga, J. (2019). The public education's indicator system. Research Centre for Economics and Regional Sciences. Institute of Economics. Budapest. Source: https://www.mtakti. hu/wp-content/ uploads/2020/01/A_kozoktatas_indikatorrendszere_2019.pdf

\section{ACT}

Act CXC of 2011 on National Public Education, Section 4§, Paragraph 25. Source: https://net.jogtar.hu/jogszabaly?docid=a1100190.tv 